\title{
真空溶融法による $\mathrm{Ti}$ 中 $\mathrm{O}, \mathrm{H}$ の分析の精度と 正確度に及㴗す諸要因の影響*
}

\author{
小田仲森** 片山 上** 遠藤 主 計**
}

Nakaaki Oda, Noboru Katayama and Kazue Endo: Influences of Critical Factors on Precision and Accuracy in Determination of Oxygen and Hydrogen in Titanium by the Vacuum Fusion Method (Determination of Oxygen and Hydrogen in Titanium II). In the previous report, the authors described that the vacuum fusion gas analysis using tin bath is an accurate and useful one for the simultaneous determination of oxygen and hydrogen in titanium. But it seems that papers on the influences of critical factors on precision and accuracy using the tin technique are scarce, so the authors have investigated about these influences and the following results were obtained: (1) It was ascertained that the operating temperature and the surface condition of graphite chips, especially its size, were the main critical factors for analytical procedures, and found that the most optimum conditions were 1920 $1950^{\circ}$ and, 18 $\sim 20 \mathrm{me}$ sh, respectively. (2) Solidification of bath and "gettering" action were observed, and we found both have tendency to decrease the rate of gas extraction. But useful techniques for restraining these influences have been found by the present authors. (3) The influence 
of $\mathrm{Cl}$ in $\mathrm{Ti}$ (produced by $\mathrm{Kroll}$ process) on the oxygen and hydrogen values was also discussed. (4) About $98 \%$ of oxygen was recovered by the proposed technique which gave about $5 \%$ deviation in the teems of coefficient of variance for $0.01 \%$ oxygen level, and about $8 \%$ for $0.001 \%$ hydrogen level. Morever, the lowest limit of determination were $0.003 \%$ for oxygen and $0.0002 \%$ for hydrogen.

(Received May 15, 1958)

\section{I. 緒宮}

著者らは先に Sn 浴による真空溶融ガス分析法を各種 $\mathrm{Ti}$ 中の $\mathrm{O}, \mathrm{H}$ の同時定量に適用して好結果を得たことを報告 した(1)。本報はさらにその精度と正確度に及ほす諸要因の 影響につき研究したものである.

Sn 浴法の 精度と正確度についてはすでに Walter (2), Yeaton(3) らの報告があるが，いずれもこれらとその要因 との関係については殆んぞ触れていない.また Albrecht ${ }^{(4)}$ らはグラファイトカバーの効果や Sn 融風の量について論 じているが，分析中に経験される各種のトラブルやその対 策, 浴の硬化, 师壁蒸着物のゲッター作用, および Kroll 法による Ti 中の共存塩素の挙動などに関する研究はいま だに殆んど報ぜられていない，他方これらの関係を明らか にすることは本法の実用性の向上や常行分析における 条件 管理などのために重要なことである．かかる考虑の下に著 者らは分析の精度と正確度に及ほす諸要因の影響について 二三の実験を行い, かつ常行分析のデータを統計的に処理 して若千の知見を得たのでこれらの成果につき報告する.

\section{II. 䓀置および材料}

装置は既報 ${ }^{(1)}$ と同様に火花間隙式高周波誘導加熱方式に よる N.R.C. 09-1240 型真空 溶融ガス 分析装置を用い た. 朋堝などのグラファイト製品は日本カーボン，日本坩 堝製の高純度品を併用し，融剤用 Sn は試薬特級品を 既 報(1)の方法で調製して使用した。

\section{III. 睹要因の影}

分析の精度と正確度に影蠁を及注す諸要因を分析法自体 に限定すれば溶融师を主体とする反応系，ガス循睘部とガ ス量測定部とよりなる分析系のおのおのに介在する要因に 大別される. 後者につき酸化銅の加熱温度やMcLeod 計の 読みに付随する俱差などを検討した結果，いずれも再現性 が極めてよいことを垫めたのでここでは前者についてのみ 検討する. その主なる要因としては(1) ガス抽出温度, (2) 反応用グラファイトチップ(以下チップと略記）の粒度とそ の性状，(3) グラファイト坩堝などの脱ガス温度とその時 間，(4) ブランク值，(5) 浴の硬化，(6) 試料および坩堝 類中の不純元素によるダッタ一作用, および (7) Kroll 法 による $\mathrm{Ti}$ 中に共存する $\mathrm{Cl}$ の挙動などが考えられる.

以下これらの影響につき (1)〜 (5) については主として 常行分析のデータをもとにして考察し，(6)，(7) について はそれぞれ実験によって検討した。 なお本報に示す常行分 析および以下の実験における試料量とチッブの量はいずれ もそれぞれ約 $0.2 \mathrm{~g}, 3 \sim 4 \mathrm{~g}$ である。

\section{1. 抽出温度, チップの粒度や性状の 影整}

$\mathrm{Ti}$ 中の H は加熱によって抽出される(2)(4)が，Oは試料

(1) 小田, 薮：チタニウム, 22 (1955), 137.

(2) D. I. Walter, Anal. Chem., 22 (1950), 297.

(3) R. A. Yeaton: Vacuum, 2(1952), No. 2, 115.

(4) M. W. Mallett, W. M. Albrecht : Anal. Chem., 26 (1954), 401.
とチッブとの高温接触による酸化還元反応により CO の形 で抽出されるから抽出温度およびチップの粒度や性状が $\mathrm{O}$ の抽出に大きく影響するものと考えられる．これらの影響 を明らかにするためにつきの条件で行った常行分析のデー 夕につき統計的解析を試みた. 分析条件のうちチップの粒 度は 14〜16, 18〜20 メッシュの 2 水準を撰び, 抽出温度 は既報の内標準試料(1) の抽出曲線を管理の基準として 1800 2000の範囲内で適宜に調節し，その他の条件は一 定とした。 また抽出時間は一定時間ごとの抽出ガス量（以 下ガス量と略記）が恒量を示すことによって判定した。こ のようにして行った総計 119 回の正常な常行分析のデータ を Table 1 に示すようにまず 2 水準の 抽出時間に層別 し,これをさらに温度 3 水準, 粒度 2 水準に群分けし，お のおのの場合の分析回教を求めた.

Table 1 Influences of operating temperature and size of chips on the extraction time.

\begin{tabular}{c|r|r|r|r|r|r}
\hline & \multicolumn{5}{|c}{ Run Number } \\
\cline { 2 - 7 } $\begin{array}{c}\text { Extraction } \\
\text { time (min) }\end{array}$ & \multicolumn{3}{|c|}{$25 \sim 30$} & \multicolumn{3}{|c}{$35 \sim 50$} \\
\hline \begin{tabular}{c|c|c|c|c|c} 
Size of Chips \\
(mesh)
\end{tabular} & & & & & \\
Operat- & $14 \sim 16$ & $18 \sim 20$ & Total & $14 \sim 16$ & $18 \sim 20$ & Total \\
ing temp. $\left({ }^{\circ} \mathrm{C}\right)$ & & & & & & \\
\hline 1900 & 4 & 12 & 16 & 8 & 7 & 15 \\
1920 & 7 & 11 & 18 & 6 & 4 & 10 \\
1950 & 10 & 30 & 40 & 12 & 8 & 20 \\
\hline Total & 21 & 53 & 74 & 26 & 19 & 45 \\
\hline
\end{tabular}

Table 1 から抽出温度は 3 水準のうち温度が高くなるに 從い†またナップの粒度は小なる場合けににれぞれ抽出 時間が短縮され、これらの場合には Table 2 のことくフ

Table 2 Blank values in various cases $(\mu \mathrm{Hg} \cdot 1)$.

\begin{tabular}{l|r}
\hline Blank value of graphite only & $3 \sim 5$ \\
Total blank (graphite+Sn flux) & $10 \sim 16$ \\
An example of oxygen value in Ti $(0.2 \mathrm{~g})$ & 160 \\
\hline
\end{tabular}

ランク值も低減されることを認めた。

なお抽出温度については $1900^{\circ}$ 以下になると Fig. 1 の ごとくに Table 1 の 3 水準に比して抽出速度が鈍る結果， ガス抽出に長時問を要しそのためにブランク值の增加や抽 出の不完全などの事例をしばしば経験した。他方 $1950^{\circ}$ 以 上ではブランク值の 増加だけではなく，7～8 個の試料を 連続分析する際にブランク值が大きく変動し精度が低下す ることを認めた。またチップについては粒度が 14 メッシ ュより大きくなるに従って反応は困難となり，逆に $20 x$ ッシュより細かくなるとガス放出が 急激な時にはチッフか 坩堝から噴出し，装置の分解掃除を余儀なくされることも

$\dagger$ 粒度を分析時間別にブールした横の合計 (16:15, $18: 10,40: 20)$ を比較することにより温度効果が 求まり，3 水準のうち高い方の $1950^{\circ}$ が有効である ことが判る.

计同じように維の合計 $(21: 26,53: 19)$ を比較する ことにより，粒度効果として 18〜20 メッシュは抽 出時間に対して有意差があることが判る. 
しばしば経験した .この現象は粒度が 14〜18メッシュの 場合でも起ることがあるのでチップの粒度以外にその性状

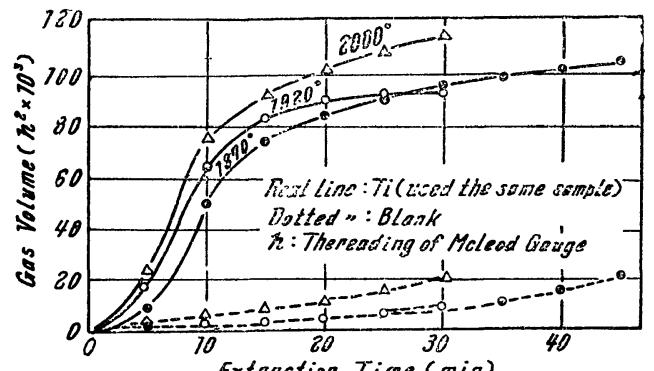

Fig. 1 Gas extraction curve of $\mathrm{Ti}$ in various operating temperature.

にも関係するようであるが明らかではない．このようなト ラブルに対しては試料分析前に予め約 $0.2 \mathrm{~g}$ の $\mathrm{Ti}$ 板を浴 に投下し $1950^{\circ}$ で $20 \mathrm{~min}, 2000^{\circ}$ で $30 \mathrm{~min}$ の加熱を順 次に行いチップを十分にシンターすることにより防止し得 ることを認めた。

\section{2. 坩堝などの脫ガス条件の影籍}

㘫堝やチッブなどのグラファイトによるブランク值の低 減とチップの反応性の堌大のためにはこれらの脱ガスをで きるだけ高温で行うことが望ましいが，グラファイトの製 造条件や性状から温度は $2400^{\circ}$ 以下に制限される ${ }^{(5)}$ 。こ
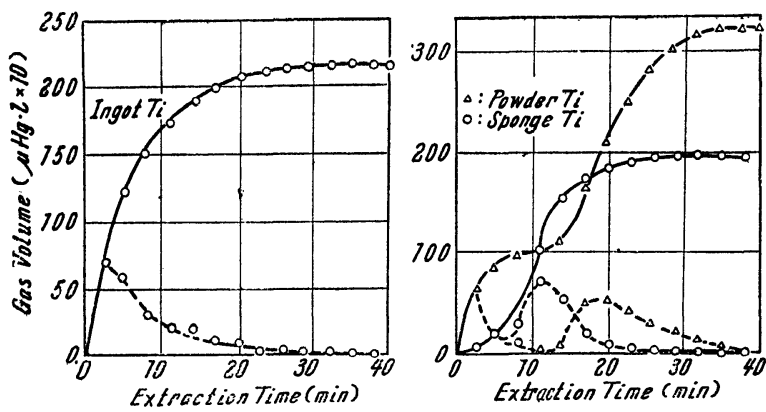

Fig. 2 Some examples of gas extraction curve at optimum condition. Real lines show the cumulative gas volume and dotted the interval.
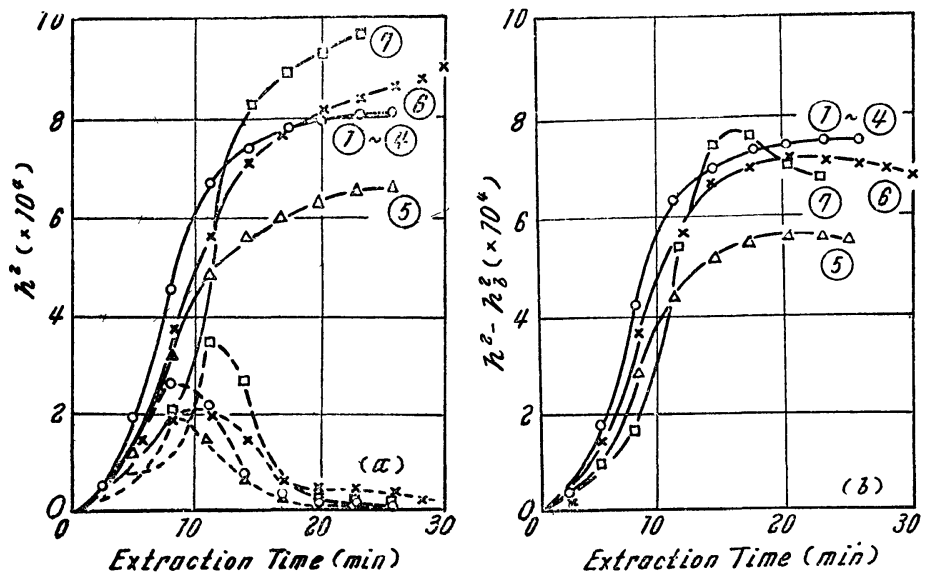

Fig. 3 Gas extraction curve in the case of solidification of bath was happened. Curve No. (1) (7) show the run order of sample. $h_{b}$ means the reading of McLeod Gauge in blank run.
のことと前述の櫴出に及注すグラファイトの反応性とを考 虑して脱ガス条件を検討した結果，抽出温度が 1900〜 $1950^{\circ}$ で注脱分スは $2300 \sim 2400^{\circ}$ で通常約 $4 \mathrm{hr}$ 行うこ とが適当であり，この条件下でのブランク值は Table 2 の 第 1 列に示すごとくに極めて小さく約 $4 \mu \mathrm{Hg} \cdot 1$ である.

\section{3. フランク値の影豚}

既報の錫調製法 (1) で調製した 錫融剂を含む 全ブランク 值を常行分析のデータで 示せば Table 2 の第 2 列に示す ごとくに極めて 小さく，その変動も無視できるほど 小さ い. しかし温度が $1950^{\circ}$ 以上になるとブランク值は Fig. 1 のごとく上述の 2〜4 倍に増え，かつその変動も大きく なる．従ってこれが分析精度低下の 原因になる可能性が大 きくなる。

\section{4. 浴硬化の影}

脱ガス温度，抽出温度，およびチップの粒度を前述の適 正条件に規正すると，Ti 試料のガス抽出は Fig. 2 に示 すごとくその 全ガス量の大小および ガス量の 時間的変化 (Fig. 2 の点線) の如何にかかわらず通常 $40 \mathrm{~min}$ 程度で 殆んど完了することを認めた。

しかるに 7〜8 個の試料を連続定量する場合にガス抽出 状態が分析順位によって異なり，中程の順位ではガス量が 上位に比して減少し逆に㷋位の試料ではガス量が増加す ることがしばしばみられた．Fig. 3 (a) は同一陚料による その一例で順位 1〜4 の曲線はほほ重なる正常な抽出曲線 を示すが，これらに比して順位 5 の曲線はかなり低 く，逆に順位 6,7 ではガス量が増加し，その勾配も 緩慢な上真を示したまま分析の終点に至っている。文 かる現像は当然分析の精度や正確度に大きな影響を及 ほすのでその原因と対策につき種々検討の結果, 分析 の途中 (通常 4 と 5 の間)でチップを浴に追加すること によりこれを防止し得ることを諗めた。このことから Fig. $3(\mathrm{a})$ の順位 5 の曲線のごときガス量の低下現 象は分析順位の增加とともに浴内に $\mathrm{TiC}$ が荎積し反 応に預かるチッブが減少するために浴が 次第に硬化 し，その結果チップと試料の接触が不十分となり，O の抽出が困難になったものと考える.このような現象 は鉄浴においてはすでに認められている ${ }^{(6)}$ が錫浴で はまだ報告されていないようである。なお上述の現 はAlbrechtら(4)の Ti 試料とチップの 重量比にはある限界が存するとの考察か らもうなずかれるように思う。つぎに順 位 6,7 のガス量が順位 5 に比して逆に 増加している現囟は区応が緩慢となった 前位試料 5 の残留ガスがこれらの時に抽 出されたものと考える.さらに順位 5 と 6，7 の現象は一見相区するようである が各順位のブランク值を差引いた試料の みの抽出曲線(Fig. 3(b)) はそれぞれあ る時間以後に降下を示すことから前位試 料の未抽出分は次位試料の分析まで浴内 に残留する以外にその一部が前位試料の

(5) E. Booth, F. J. Bryant \& A. Paker : Analyst, 82 (1957), 50.

(6) R. S. McDonald, J. E. Fagel \& E.W. Wallis: Anal. Chem., 27 (1955), 1632. 
直後に行われるブランク値の測定の時にも抽出されている ことが判る.たとえば Fig. 3-(a) の順位７の試料のよう に見掛け上のガス量 $\left(h^{2}\right)$ が他に比して増加していても試料 のみのガス量 $\left(h^{2}-h^{2}\right)$ は Fig. 3-(b)にみられるごとく減 少している.

つぎに浴の硬化を避けるために 分析途中で抽出温度を高 めることも試みたが逆に硬化が促進されることを認めた。 このことは抽出温度を高めることにより $\mathrm{TiC}$ の生成が一 層助長されたものと推定され，上述のガス量低下は浴の硬 化によるとの考察を裹付けるものと考える。

\section{5. ゲッター作用の影婹}

坩堝の保持や熱絶縁に同一グラファイト粉末を長期間連 用して分析した場合，ガス量が Fig. 4 (全部同一試料使 用）のごをくに順位 5 以後が漸次低下し，かつ前述の浴硬 化と異なる現象を経験した。この原因につき検討の結果， かかる場合には忓壁にゲッタ一性の触い $\mathrm{Al}, \mathrm{Ca}$ などを含 む喑黒色の蒸着薄膜の形成がみられ，上述の異状現象はか かる薄膜のゲッタ一作用によるものと推定してつぎのごと

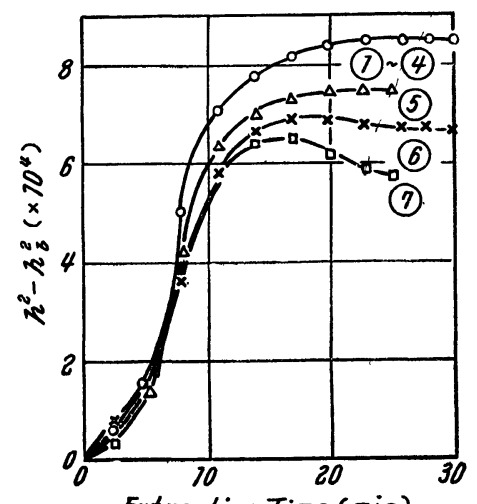

Extraction Time (min)

Fig. 4 Gas extraction curve in the case of "gettering" action was happened.

き確認実験を行った。すなわち同一試料を用い浴に Sn を 添加した場合と添加しない場合の抽出曲線を比較した結

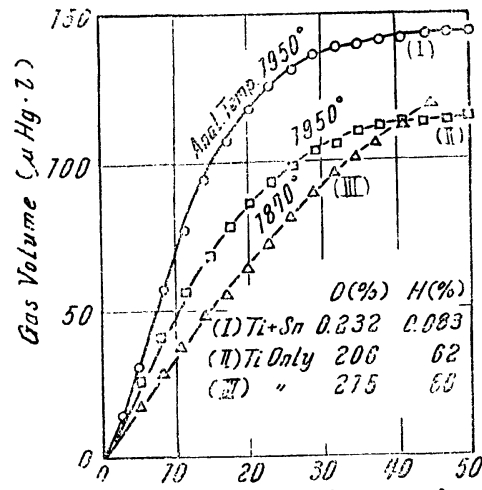

Extraction Time (min)

Fig. 5 Comparison of gas extraction curves in the case of $\mathrm{Sn}$ added and not.

果, Fig. 5 のごとくにそれぞれ ガス量は異なるが曲線の 形状が相似し，かつ Sn 不添加の場合には抽出曲線は Fig. 4 の異常現象の場合と同様な傾向を示すことを認めた。こ れらのことから上述のガス量の低下は浴の硬化によるもの
そは考えられない. 他方グラファイト粉末の使用回数を制 限し，または粉末を酸処理後十分に洗滌乾燥してから使用 するなどの対策を講ずると薄膜の形成およびガス抽出の異 常現象を著しく低隇し得ることを知見した。このようなこ とから薄膜の形成はグラファイト粉末の性状およびその使 用期間の長短などに関係するものと推定され，上述のガス 抽出の異常現象は薄膜のゲッター作用に起因するものと考 える.

\section{6. 共存塩素の举動}

$\mathrm{Ti}$ に共存する $\mathrm{Cl}$ の影響を検討するためにつぎの実験を 行った. すなわち $\mathrm{Cl}$ 約 $0.1 \%$ 含む Kroll 法 $\mathrm{Ti}$ を試料 とし，分析装置の师とポンブを結ぶガス導管内に $\mathrm{Cl}$ 固定 用銀網 $\left(250 \sim 350^{\circ}\right.$ に加熱)を挿入し，その他の条件は既述 の常行分析と同様にして 6 試料連続分析した結果を 銀網を 挿入しない場合の分析值と比較した.そ）結果銀網の挿入 はガス抽出曲線および $\mathrm{O}, \mathrm{H}$ の分析結果に影響を及ほさ ずまた分析後の銀網には $\mathrm{Cl}$ が捕捉されていないこと， および上述のいずれの場合にも忓壁から $\mathrm{Mg}$ が検出される ことが判った．つぎに $\mathrm{Mg}$ を含まない沃化法 $\mathrm{Ti} に \mathrm{MgCl}_{2}$ を添加した試料につき同上の実馀を行い，炉壁蒸着膜の分 光分析の結果 $\mathrm{Mg}$ が存在することを認めた．以上の結果か ら Kroll 法 Ti のように Cl が遊離状態ではなく主とし て $\mathrm{MgCl}_{2}$ の形で存在すると洘えられる場合には $\mathrm{Cl}$ は一 忍 $\mathrm{MgCl}_{2}$ のままで师壁に凝結し 分析系内一は導入されて いないものと考える. 従って Kroll 法 Ti 中に共存する $\mathrm{Cl}$ は $\mathrm{O}, \mathrm{H}$ の分析結果に影響を及ほさないものと推定す る.

\section{IV. 適正分析条件における 正確 度と精 度}

前述の適正条件における正確度を検討するために沃化法 で精製した純 $\mathrm{Ti} に$ に純度既知の $\mathrm{TiO}_{2}$ を添加し溶融せずに そのまま $\mathrm{Sn}$ 箔で包みそのO 回收率を測定した結果を Table 3 に示す.

Table 3 Accuracy of analysis (oxygen recovered).

\begin{tabular}{|c|c|c|c|c|c|c|}
\hline 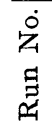 & 营. & 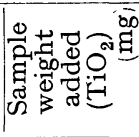 & 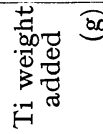 & Q0. & 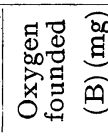 & 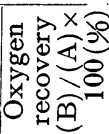 \\
\hline I & $\begin{array}{l}1 \\
2 \\
3 \\
4\end{array}$ & $\begin{array}{l}1.446 \\
0.618 \\
1.279 \\
0.796\end{array}$ & $\begin{array}{r}0.1744 \\
2015 \\
1999 \\
1990\end{array}$ & $\begin{array}{r}0.5784 \\
2472 \\
5116 \\
3184 \\
\end{array}$ & $\begin{array}{r}0.5683 \\
2418 \\
4993 \\
3124 \\
\end{array}$ & $\begin{array}{l}98.3 \\
98.0 \\
97.8 \\
98.1\end{array}$ \\
\hline II & $\begin{array}{l}5 \\
6\end{array}$ & $\begin{array}{l}1.481 \\
0.862\end{array}$ & $\begin{array}{l}2029 \\
1965\end{array}$ & $\begin{array}{l}5924 \\
3448\end{array}$ & $\begin{array}{l}5804 \\
3401\end{array}$ & $\begin{array}{l}98.0 \\
987\end{array}$ \\
\hline III & 7 & 1.482 & 2008 & 5928 & 5874 & 99.1 \\
\hline & & & & & $\begin{array}{l}\text { Mean } \\
\text { Stand. } \\
\text { dev. }\end{array}$ & $\begin{array}{r}98.3 \\
0.4\end{array}$ \\
\hline
\end{tabular}

$\mathrm{Sn}$ 浴法によるO回収率についてはすでに Walter ${ }^{(2)}$ と Mallett(4) らの報告があり，前者はO $\mathrm{O}$ を吸着させた $\mathrm{Ti}$ お よび $\mathrm{Ti} に \mathrm{TiO}_{2}$ を加えて溶融したものについていずれも 略て $100 \%$ に近い回収率を得ている. また後者は沃化法 による $\mathrm{Ti}$ 棒中に $\mathrm{TiO}_{2}$ を埋めてアーク溶融したものを試 料とし，ほほ同上の結果を得ている. しかしいずれもその 実験内容の詳細および測定の精度などが明らかにされてい ないので，それらの結果と Table 3 の測定值との比較㭘 
討は困難である、しかしＯの堌減を伴いやすい溶融処理を 避けた試料による著者らの実験が $98.3 \%$ の回収率を示 し，かつ試料形態を異にする前二者の結果とかなりよい一 Table 4 Precision of analysis.

\begin{tabular}{|c|c|c|c|c|c|c|}
\hline $\begin{array}{l}\text { Analytical } \\
\text { elements }\end{array}$ & \multicolumn{3}{|c|}{$\mathrm{O}$} & \multicolumn{3}{|c|}{$\mathrm{H}$} \\
\hline $\begin{array}{l}\text { Sample No. } \dagger \\
\text { Run No. }\end{array}$ & 1 & 2 & 3 & 1 & 2 & 3 \\
\hline 1 & 0.078 & 0.097 & 0.216 & 0.0007 & 70.0010 & 0.0984 \\
\hline 2 & 74 & 94 & 222 & 6 & $3 \quad 11$ & 956 \\
\hline 3 & 80 & 96 & 218 & 6 & 9 & 935 \\
\hline 4 & 79 & 89 & 225 & 7 & 10 & 904 \\
\hline 5 & 77 & 90 & 226 & 9 & 9 & 952 \\
\hline 6 & 77 & 101 & $21:$ & 8 & 10 & 947 \\
\hline 7 & 78 & & 220 & 7 & & 961 \\
\hline 8 & & & 219 & & & 940 \\
\hline 9 & & & 238 & & & 940 \\
\hline 10 & & & 222 & & & 924 \\
\hline$\frac{11}{M}$ & & & 232 & & & 908 \\
\hline $\begin{array}{l}\text { Mean } \\
\text { C. V }(\sigma(\%))\end{array}$ & 0.078 & 0.095 & 0.223 & $0.000 \%$ & 0.0010 & 0.0936 \\
\hline C. V. $(\sigma(\%))$ & 3.4 & 4.2 & 3.4 & 15 & 7.5 & 2.1 \\
\hline
\end{tabular}

$\dagger$ Sample No. 1,2 and 3 means sponge, powder, and ingotttitanium, respectively.

致を示すことから上述の分析条件は適正であり，本法沬信 頼度が高いと考える.なお Table 3 の結果が $100 \%$ を僅
かに下䞡る値を示す原因については今後浴中に残留する $\mathrm{O}$ 值などからも検討したいと考えている．つぎに本法の精度 は Table 4 のごとく低 H 域 (0.001\%) を除けばいずれ も再現性は極めてょく，定量範囲はＯ 2 0.003\%, H 0.3 〜0.0002\%であることを認めた。

\section{V. 結}

以上を要約するに真空溶融法による $\mathrm{Ti}$ 中 $\mathrm{O}, \mathrm{H}$ の分 析の精度と正確度に及ほす諸要因の影響および從来しばし ば経験された二三の異常現象の 原因とその対策を明らかに し，かつこれらの結果から本法の適正分析条件を求めた. また $\mathrm{Ti}$ 中共存 $\mathrm{Cl}$ は $\mathrm{O}, \mathrm{H}$ の分析結果に影響を及ほさ ないことを実験的に認めた・本法による精度を変異係数で 示すと O $5 \%$ 以内, H $8 \%(0.001 \%$ 水準 $), \mathrm{O}$ の回收率は 約 $100 \%$, 定量下限は O $0.003 \%, H 0.0002 \%$ ある.

終りに本稿に対し 御討議下さったチタニウム懇話会分析 委主査宗宮尚行博士，ならびに御討嶬と御校閲を頂いた東 北大学金属材料研究所後藤秀弘教授および本研究に対し終 始御懇切な御鞭鞋と御配虑を頂いた日本曹達株式会社社長 大和田悌二氏，副社長田中東馬氏，常務取締役大我勝躬氏， 取締役高岡工場長日比野英一氏を始め上司各位に対し謹ん で深甚なる敬意と謝意を表する。 